\title{
Against a Postmodern Pentecostal Epistemology
}

\author{
RichaRd B. DAVIS \\ Department of Philosophy \\ Tyndale University College \\ Toronto, Canada \\ W. PAUl FranKS \\ Department of Philosophy \\ Tyndale University College \\ Toronto, Canada
}

It is well-nigh axiomatic that the role experience plays in the life of the Spirit-filled believer is a sine qua non for any pentecostal ${ }^{1}$ theology or view of the world. It is not surprising, therefore, to discover that pentecostals lay a heavy emphasis on story or narrative - a perfect vehicle for testifying to one's personal experiences of God. Indeed, according to pentecostal philosopher James K. A. Smith, not only do we "know in stories," we are "narrative animals." ${ }^{2}$ Pentecostals will thus see a "deep affinity between postmodernism and a pentecostal worldview,"3 since postmodernists also strongly favor knowing by way of affective narrative instead of by amassing evidence for the objective truth of one's propositional beliefs.

Now of course there is nothing wrong with stories. Jesus often told them (to splendid effect) in his teaching ministry. But what if you were told that everything is a story-yourself included? On the face of things, that seems a little odd. Alas, however, it's de rigueur for being a contemporary postmod-

ABSTRACT: In this paper we explore the idea that pentecostalism is best supported by conjoining it to a postmodern, narrative epistemology in which everything is a text requiring interpretation. On this view, truth doesn't consist in a set of uninterpreted facts that make the claims of Christianity true; rather, as James K. A. Smith says, truth emerges when there is a "fit" or proportionality between the Christian story and one's affective and emotional life. We argue that pentecostals should reject this account of truth, since it leads to either a self-refuting storyrelativism or the equally problematic fallacy of story-ism: favoring one's own story over others without legitimate reason. In either case, we contend, the gospel itself is placed at risk.

1. In using small- $p$ "pentecostal" we are following Smith and also mean to use it as a "gathering term, indicating a shared set of practices and theological intuitions that are shared by Pentecostals, charismatics, and 'third wavers"' (Thinking in Tongues (Grand Rapids, MI: Eerdmans, 2010), xvii).

2. Smith, Thinking in Tongues, 44.

3. Ibid. 
ern Christian. For example, in a piece entitled "Who's Afraid of Postmodernism? A Response to the "Biola School,", Smith insists that even "the world is a kind of text [story] requiring interpretation."4 Unfortunately, due to our situatedness (ethnic, historical, and otherwise), we never really get at that world: "So we never get past texts and interpretations to things 'simply as they are' in any unmediated fashion . . . rather, we move from interpretation to interpretation. The entire world is a text. Thus, 'there is nothing outside of the text." "We can never know the noumenal world of the Nazarene, the world in which he carried out his ministry of miracle working and exorcisms, where he was crucified, buried, and then raised on the third day. We're stuck only with the phenomena: the various interpretations of it. But, says Smith, we are not to worry: "I see no reason why such a claim is antithetical to Christian Faith."

In what follows we aim to provide an extended examination and critique of Smith's interesting epistemological project, one that, as far as we are aware, is not present in the literature. ${ }^{7}$ We shall argue that Smith's commitment to everything being a story in need of interpretation, which divorces the truth of Christianity from the objective facts, results in either a self-refuting story relativism or the equally problematic fallacy of story-ism: favoring one's own story over others without legitimate reason. In either case, we shall contend the gospel itself is placed at risk.

\section{The Story about "Stories"}

Well, how does it all work? First of all, we should be clear about what a "story" is. Very roughly, it is "a sequence of events with a narrative arc, with a crisis and complications" and perhaps building to a climax. ${ }^{8}$ Now this

4. In Christianity and the Postmodern Turn: Six Views, ed. Myron B. Penner (Grand Rapids, MI: Brazos, 2005), 225.

5. Smith, "A Response to the 'Biola School,", 225.

6. Ibid.

7. R. Scott Smith and R. Douglas Geivett have both provided critiques of Smith, but we believe they do not go far enough in their evaluation of his view. E.g., in "Postmodernism and the Priority of the Language-World Relation" (in Christianity and the Postmodern Turn) R. Scott Smith devotes only five paragraphs to Smith's position and the substantive concern is Smith's rejection of a "God's-eye-view" of reality; hence, we "cannot get outside our language and know an objective extralinguistic world" (175). Further, in R. Scott Smith's "Finitude, Fallenness, and Immediacy: Husserlian Replies to Westphal and Smith" (Philosophia Christi 13 (2011): 105-26), the main point of contention is that Smith's interpretation of Husserl is wrong, and thus, so are the conclusions based upon that wrong interpretation. Our critique of Smith depends on neither of these points (see footnote 23 below for more on this). In "Postmodernism and the Quest for Theological Knowledge" (also in Christianity and the Postmodern Turn) Geivett also presents various objections to Smith's epistemological project, but that exchange predates Smith's Thinking in Tongues by five years and it is in that book that one can see how Smith would likely respond to Geivett's objections (see footnote 10 below for more on this).

8. Smith, Thinking in Tongues, 62. 
isn't quite right, of course, if we're insisting that everything is interpretation. A story or narrative - Smith uses these terms interchangeably — would be an interpretation of a sequence of events, not the events themselves. Further, stories aren't reducible to sets of knowable propositions that correspond to external reality; rather, they constitute "a different kind of knowing, knowledge of a different order, on a different register" — an affective or emotional knowing in which "The truth is the story; the narrative is the knowledge." 10 Thus, we don't say that the Christian story is true because it corresponds with something outside itself (the facts) which serves to ground its truth. The story isn't made true at all—or at least we can't know that it is; instead, the story just is the truth all on its own.

A driving force behind Smith's rejection of truth as a correspondence with extramental, extralinguistic reality seems to be his allegiance to a particular hermeneutical claim, originally made famous by Jacques Derrida: there is nothing outside the text. According to Smith, this initially cryptic assertion doesn't mean that "everything is a book, or that we live within a giant, all-encompassing book, but rather that everything must be interpreted in order to be experienced." 11 A bit more precisely, "we could loosely translate 'There is nothing outside the text' simply with the axiom 'Everything is interpretation'. Or, in other words, 'It is interpretation all the way down." 12 For ease of reference, then, let's define Derrida's Axiom (DA, for short) as the claim that everything is an interpretation.

Now at this point, Smith concedes that "many Christians become nervous and assume that the claim that 'everything is interpretation' is antithetical to Christian faith." ${ }^{\prime \prime 3}$ But, he insists, "there is a problem with this conclusion." ${ }^{14}$ In particular, it "rests on a faulty premise, namely, a serious misunderstanding" 15 of DA. Smith identifies three reasons for Christian suspicion of DA: two are said to be based on outright misunderstanding; the third embodies a modernist concept of knowledge that "doesn't match up with the witness of the New Testament." ${ }^{16}$ Let's say a brief word about each of these.

9. Ibid., 64.

10. Ibid. In effect, this constitutes Smith's response to R. Douglas Geivett's earlier (2005) demand, namely, that "[Smith] owes us an account of how narrative (or myth) can be truth-conducive, how a narrative or myth can make it likely that what is believed is true" ("Postmodernism and the Quest for Theological Knowledge" in Christianity and the Postmodern Turn, 165). Smith's answer, essentially, is that something like the Christian story is true - narrativally true, we might say - by virtue of its "making sense" of our affective (/emotional) lives and experience. We turn to this interesting claim in the final section of our paper.

11. James K. A. Smith, Who's Afraid of Postmodernism? Taking Derrida, Lyotard, and Foucault to Church (Grand Rapids, MI: Baker Academic, 2006), 39.

12. Ibid., 42.

13. Ibid.

14. Ibid., 35.

15. Ibid.

16. Ibid., 48. 
The first suspicion is that if there were nothing outside the text-that is, if DA were true - then "a transcendent Creator who is distinct from and prior to the world could not exist." follow that "what the Bible (admittedly a text) talks about-what it refers to - is not real." ${ }^{\prime 18}$ Smith helpfully clears up these misunderstandings of DA. Like Kant, Derrida isn't teaching that there is no noumenal world of things in themselves. As Smith himself concedes, there is a "structural horizon"19 outside all interpretations, namely, "worldly states of affairs - the world as given and experienced." ${ }^{20}$ Nevertheless, Derrida and Smith unite as one man in declaring that the interpretation "does not deliver the world as it 'really is." "21 Rather, we "see' the world through the lens of an interpretive tradition that delivers it "as' something." 22 Our experience is always and only of things as interpreted (that is, the phenomena). And this leads, like it or not, to a plethora of differing interpretations each of which is

informed by a number of different things: the context in which I encounter the thing, my own history and background, the set of presuppositions that I bring to the experience, and more. Given all these conditions, the things I experience are subject to interpretation - and as such, they are subject to different interpretations. ${ }^{23}$

Of course, this raises the further worry: if Derrida's Axiom is true, and we are awash in a sea of differing interpretations, then haven't we landed in a

\section{Ibid., 35 .}

18. Ibid.

19. See James K. A. Smith, The Fall of Interpretation: The Philosophical Foundations for a Creational Hermeneutic, 2nd ed. (Grand Rapids, MI: Baker Academic, 2012), 186.

20. Ibid., 181.

21. Ibid., 185.

22. Ibid., 175.

23. Smith, Who's Afraid of Postmodernism?, 40. This same paragraph appears verbatim in "A Response to the "Biola School," 217. The claim therein is presented as a reply to Scott Smith's charge that on (James) Smith's view "our only contact with [the] world is by our language" (ibid., 221). The worry, then, is how epistemic access to extralinguistic reality is even possible. According to (James) Smith, this concern embodies a faulty, overly narrow view of language. In a broader sense, however, there is no question of how I might "get around" language to the world, since "the world I inhabit [of things, events, and people] is always already interpreted within a framework of signs" (ibid., 222).

Now, so far as we can see, Scott Smith's basic reply here has been to say that this move on (James) Smith's part depends on the mistaken belief that "Husserl is wrong that we can have immediate access to things in themselves." We can enjoy this access - e.g., by way of "simple seeing," where extralinguistic reality is apprehended directly (see R. Scott Smith, "Finitude, Fallenness, and Immediacy," 121). Of course, brute appeals to "simple seeing" as a means of settling differences between the two Smiths are purely question-begging in this context. For here (James) Smith can - and indeed does - maintain that (1) there is an extralinguistic world, (2) we don't have direct epistemic access to it; however, (3) God has supplied us with its correct understanding by virtue of giving us the right set of presuppositions for interpreting the world (see "A Response to the 'Biola School," 218). So the root issue here is not really "simple seeing," but rather the viability of Smith's presuppositionalism. This is addressed in detail below. 
kind of story relativism in which no interpretation of reality is (or can be known to be) the fact of the matter? This is precisely what follows, we'll argue, and Smith's attempts to evade the ravages of relativism here are by no means encouraging.

A third suspicion follows on the heels of the second. If DA is true, then "even the gospel is only an interpretation and not objectively true." ${ }^{24} \mathrm{We}$ think this is a far greater problem than Smith is willing to admit. He attempts to defuse the issue by pointing out that acquiring this sort of truth is wholly unrealistic, in which case we shouldn't be troubled if the gospel isn't objectively true. Thus Smith:

Christians ... are usually hanging on to a very modern notion of knowledge, one that claims something is true only insofar as it is objective - insofar as it can be universally known by all people, at all times, in all places. On this account, the truth of the gospel . . . is taken to be objectively true and thus capable of rational demonstration .... If we say that the gospel is an interpretation, then it is not objectively true in the traditional or modern sense of being self-evident or universally demonstrable. ${ }^{25}$

So the idea is that if the gospel were objectively true, it would be self-evident to everyone; no one could or would deny it, since it would either be as obvious as seven and five's equaling twelve, or capable of being shown to be true by a rationally inescapable proof (as with the Pythagorean theorem). Smith then rightly notes that not everyone does accept the gospel; some see things differently, perhaps because as the Apostle Paul says, "their senseless minds were darkened" (Rom. 1:21). And thus, Smith concludes, the gospel is neither self-evident nor rationally demonstrable. Hence, it's not objectively true. There is nothing to worry about.

But here there is confusion. The problem, fundamentally, is that Smith doesn't have a proper grasp of the concept of objective truth. To say that a proposition $p$ is objectively true is only to say that our thinking or feeling that $p$ is true doesn't make it true. Rather, the truth of $p$ obtains by virtue of the way things are in the world. ${ }^{26}$ And there is nothing in this concept which implies that everyone can just see that a given proposition is true. In fact, wouldn't things be the other way around? If truth were subjective-if it depended, say, on what we believed or what seemed true to us - then yes, without so much as breaking a sweat, everyone could "get" the truth just by knowing what they believed. Actually, there wouldn't be any "getting" at all; everyone would already have the truth simply by having their opinions.

To the contrary, one thinks that it might be very difficult indeed to come to know some objective truths. Take, for example, the proposition gold is

24. Smith, Who's Afraid of Postmodernism?, 42.

25. Ibid., 48.

26. We are thankful to Mike Almeida for helping us make this point more clearly. 
atomic number 79. Surely this is an objective truth. It's based on a scientific fact about the atomic structure of gold that scarcely depends on human opinion. Of course, we always knew that gold was a yellow metal. (Immanuel Kant mistakenly thought this was a necessary truth about gold.) But we didn't always know that the nucleus of this element contains seventy-nine protons. As a matter of fact, we didn't even know there were protons in the nucleus of an atom until the discovery was made by the English physicist Henry Gwyn-Jefferies Moseley in 1913. Did Moseley just see that gold is atomic number seventy-nine simply by thinking about the relevant proposition? Did he quickly deduce it from a few self-evident axioms? Certainly not. He was a researcher at Oxford University. At great financial and intellectual cost, he developed the equipment and pioneered the technique involved in x-ray spectroscopy. That's how the discovery was made.

Now, of course we're not saying that this is how we come to know the gospel-under the microscope, as it were. What our little example does show, however, is that Smith has badly confused the truth conditions for a proposition - that is, those aspects or features of reality that make it true-with our knowing or discovering that it is true. It's a basic category mistake. A proposition (claim, assertion) can be objectively true even if it's not self-evident, rationally demonstrable, or even known at all. And so this third worry about DA - that it implies the gospel is a mere interpretation-remains in force.

In fact, Derrida's Axiom appears to contradict the express teaching of scripture. For consider Peter's Axiom (PA): "No prophecy of scripture is a matter of one's own interpretation" (2 Pet. 1:20). According to PA, there are some things that are not the result of someone's interpretation-namely, prophecies of scripture, which would of course include PA itself. But DA tells us something quite different; it says that everything (including Peter's Axiom) is the result of interpretation. So if Derrida's Axiom is true, Peter's Axiom is false and scripture is in error. If Peter's Axiom is true, then it's Derrida's Axiom that is false. So this is one of those cases where you have to choose this day whom you will follow: either the Apostle Peter, who under the inspiration of the Spirit wrote 2 Peter 1:20, or the postmodern philosopher Jacques Derrida who, we may safely presume, wasn't thus inspired. For pentecostal Christians, the choice should be easy. ${ }^{27}$

But let's suppose, for argument's sake, that Derrida's Axiom is true, so that everything is a story or interpretation. The question arises: why tell

27. Objection: "you say that DA is the claim that everything is an interpretation. However, it is more accurate to say that everything we experience is an interpretation. Hence, your argument misses the mark." Reply: this nuance won't matter in the present case; PA will still contradict DA. We can see this as follows: PA teaches that no prophecy of scripture is the result of interpretation; but PA is itself a prophecy of scripture; hence, PA teaches of itself that it is not the result of interpretation. However, if we accept the suggested revision of DA, Peter's Axiom is an interpretation, namely, the one Peter gives to his experience of being "moved by the Holy Spirit" (2 Pet. 1:21). 
stories at all? Here the connection between Smith's epistemology and his anthropology becomes explicit. ${ }^{28}$ We tell stories because each of us has an "affective register"- a buzzing and disorderly array of emotions - that cries out for organization. And these emotions, says Smith, are themselves "hermeneutic filters, 'noncognitive affective appraisals' doing the work of interpreting our world." ${ }^{29}$ In other words, our many little interpretations of reality (emotions) find themselves in need of organization. A story is a larger interpretive context which serves to do that on an affective or emotive level. Moreover, for those fortunate enough to hit upon the right story, there is "a kind of 'fit' or proportionality between narrative and our affective register" 30 which "makes sense" of our lives and experience. And surely that is what we all want.

\section{When the Story Doesn't "Fit"}

Now Smith doesn't exactly tell us what "fit" amounts to; however, it's pretty clear that he's not thinking of a matching relation between a story line and the extra-affective, mind-independent reality it might be about. It's a "fit" between interpretations: an affective storyline and a particular individual's affective register. These aren't the same of course, since if they were we wouldn't need the former to "make sense" of the latter. The mention of proportionality suggests an overlap or similarity of (affective) elements between the two with the story adding something new and different, something not present in our emotions alone.

And what precisely is that? Here two possibilities come to mind. The first is that the story (call it $S$ ) is a kind of second-order interpretation of one's affective register. But this immediately raises a problem. If everything is a text, as Smith holds ${ }^{31}$ and if all texts require interpretation, then $S$ is a text requiring interpretation, in which case we must tell a further story, another level up in the hierarchy. But then that story, too, will require interpretation. You can see where this is going - a never ending stack of stories, one upon

28. Simply put, the connection is this. Pentecostal experience presupposes a particular philosophical anthropology - one according to which we are "narrative animals" who "traffic in the stuff of story" (Thinking in Tongues, 43). We not only make stories, we are made by them. Stories serve anthropological purposes; they set things in order and impose meaning at the level of human affections and emotions. We probe the viability of the link Smith forges between his anthropology and theory of knowledge in substantial detail in the next section of our paper.

29. Smith, Thinking in Tongues, 66.

30. Ibid.

31. Smith, Who's Afraid of Postmodernism?, 39. Compare also "A Response to the 'Biola School, $", 225$. 
another, with any chance of getting the final word (or meaning) on any story being infinitely deferred. ${ }^{32}$

We can also think of it this way. If $S$ can only "make sense" of my affective register provided that there is a higher level story $S^{*}$ that "makes sense" of $i t$, and if there is no end to the escalating stacks of stories, then nothing (including my present unruly brood of affections) is ever going to ultimately "make sense." At some point, stories must come to an end. To stop the regress, we must arrive at a story that is grounded in a nonstory - something that isn't itself an interpretation of reality. We take it that this is exactly what happened to Saul on the road to Damascus. When the pre-apostle is told, "I am Jesus, whom you are persecuting" (Acts 9:5), it's not story time with Jesus requiring a further interpretation. Not by a long shot. It's a blunt factual statement about the way the world really is, and issued by the one who made it that way. End of story. The same thing happens on the day of Pentecost. The mockers in Acts 2 interpret speaking in tongues as drunkenness: "They are filled with new wine" (verse 13). But Peter refutes this by pointing out that this interpretation isn't supported by the facts: "these are not drunk, as you suppose, for it is only nine o'clock in the morning" (verse 15).

Now in one place, Smith seems to be sympathetic to this view. ${ }^{33}$ There are two ways to interpret the world, he says: the believer "sees" it as God's creation; the unbeliever, whose thinking is "futile" and heart "darkened" (Rom. 1:21), does not. Even for firsthand observers of the crucifixion, an interpretation of the event must be given. This explains why one centurion recognized that Jesus was indeed the Son of God, while the others did not. They observed the same event, but interpreted it differently. The fact that the same event can generate vastly different interpretations leads to a problem that Smith recognizes. "Can any interpretation be excluded as 'false'? And if so, on what grounds?" 34 This raises the question of how we are to separate the good from the bad. Here the Apostle Peter can appeal to the facts; Smith cannot.

\section{The Fallacy of Story Relativism}

Instead, Smith's approach to resolving this problem is to note that any true interpretation must have two important features. First, it must recognize

32. Scott Smith briefly notes the possibility of an infinite regress of interpretations in "Finitude, Fallenness, and Immediacy," 122-3. Unfortunately, he falsely assumes that the only way for (James) Smith to terminate the regress is by "appeal to access to things in themselves" (ibid., 123). There is another possibility that Scott Smith does not seriously consider though - the one (James) Smith actually takes, namely, appealing to a primitive set of divinely given presuppositions "to interpret the world well" ("A Response to the "Biola School," 218). This regressstopping option has tended to be overlooked by Smith's critics.

33. Smith, "A Response to the "Biola School," 218.

34. Smith, The Fall of Interpretation, 176. 
that there is an "interpretive norm, which stands before (or even 'outside of') interpretation," and that "constitutes the phenomenological criterion of every construal." That is, it cannot ignore the fact that there are "empirical transcendentals" that are "binding upon interpretation." ${ }^{35}$ To borrow one of Smith's examples: if I were to interpret the tree outside my window as chimerical, that interpretation would "quickly prove itself wrong" upon attempting to run through its trunk. For the tree is "'outside" of me" and "not 'mine' to be manipulated. As such it imposes upon me limits for its interpretations; bad interpretations will be precisely those construals that transgress those limits. ${ }^{136}$ For Smith, the existence of this interpretive norm allows us to deny that there is a single true interpretation, while at the same time denying there are an "infinite number of interpretations." 37

Adherence to an interpretive norm, however, is not a sufficient condition for a true interpretation. This leads to the second feature that all true interpretations must possess-faithfulness to the communal context in which the interpretation is given. Smith's reflections on Derrida suggest that a reinterpretation of Derrida's Axiom is needed. We ought to take it rather as the claim that interpretation is determined by context. As Smith notes, to say that everything is interpretation "means nothing other than: there is nothing outside of context," and it is context that "determines the meaning of a text, the construal of a thing, or the 'reading' of an event." 38 Thus, he says, it was the context of the antebellum South that led Christian slaveholders to use the Bible to justify the practice of slavery. Our own experience, though, tells us that Derrida is right about context: "people and groups do interpret the Bible in all kinds of ways, and they do make the Bible say whatever they want it to say." However, this "does not mean that all these interpretations are good or true." $" 39$

What makes for a good interpretation, then, is that it stems from an appropriately determined context, one given by "a community of interpreters who come to an agreement about what constitutes the true interpretation of a text, thing, or event. Given the goals and purpose of a given community, it establishes a consensus regarding the rules that will govern good interpretation." ${ }^{\prime 40}$ Here then is the remainder of the method for sifting good interpretations from bad. However, it is doubtful that this appeal to com-

35. Ibid., 181 (emphasis in original).

36. Ibid. Interestingly, substituting "reality" for Smith's "interpretive norm," and "belief" for his "interpretation" makes it clear that he is functioning with a rudimentary correspondence theory of truth. Our belief that the tree was chimerical would prove false once we came into contact with reality - the actual tree trunk.

37. Ibid., 182. However, it may be worth pointing out that elsewhere Smith writes that interpreting the world as God's creation is "the true interpretation" (emphasis added). See "A Response to the "Biola School,"' 218.

38. Smith, Who's Afraid of Postmodernism?, 52.

39. Ibid., 53.

40. Ibid. 
munity will do all that is required of it. For it only pushes the problem back a notch: from individual interpreters doing what they want with a text, to a community doing what it wants with a text. To borrow Smith's example: one might well think that Christian slaveholders in the antebellum South constituted a community of interpreters. Their rules for interpretation resulted in the biblical justification for slavery, and that interpretation was warranted since that community deemed it so. That this now strikes us as absurd is not (on the present view) the result of our having come to see that slavery is objectively wrong. Not at all. Rather, we think it outrageous only because we are barred by the rules of our community from holding such an interpretation. There is nothing more to it than that.

Or consider the same problem from a distinctly pentecostal perspective. Pentecostals and cessationists form distinct communities with distinct rules of interpretation. If Smith is right, each community has come to an agreement about what constitutes a true interpretation based on its internal rules. However, each affirms what the other denies. If community agreement settles an interpretation, we have a clear case in which opposing interpretations are both true (for the respective communities), and yet there is no way, objectively speaking, to settle the difference.

Further, it would be a mistake to attempt to remedy these sorts of problems with appeals to "authorial intent" because that too is decided from within the community. On this, Smith writes, "Discerning the author's intentions can only unfold as a communal discernment." Surely many will find this problematic. Most interpreters of Scripture are concerned with ascertaining what the author of the text actually meant, not just what a community took the author to mean. However, the problem for Smith deepens. Smith also goes on to employ Derrida's additional claim that "the determination of what counts as authorial intent is, to some scandalous extent, determined by the community." ${ }^{\prime 2}$ If this is right, then there is nothing to prevent the community of antebellum slave-holders from determining that Noah intended to provide a theological basis for slavery when he cursed Canaan (Gen. 9:25). ${ }^{43}$ While Smith may be comfortable in saying that this "might just be the scandal of a theological interpretation of Scripture," 44 we are not.

An additional worry. On the present way of thinking, an individual's moving from one interpretive community to another would seem to be unwarranted. For example, nothing in what was then Paul's interpretive community would have permitted him to take his Damascus road experience as one of the risen Lord. In fact, on Smith's view, wouldn't Paul's interpretation of his experience have been false? After all, it actually contradicted his com-

41. Smith, The Fall of Interpretation, 216 (emphasis in original).

42. Ibid., 217 (emphasis in original).

43. For more on the biblical rationale for slavery, see Stephen R. Haynes, Noah's Curse: The Biblical Justification of American Slavery (Oxford: Oxford University Press, 2002).

44. Smith, The Fall of Interpretation, 217. 
munity's standards of interpretation. Indeed, it wouldn't have been until Paul had already joined the Christian community that his interpretation would have been any good. But then if the initial interpretation was bad, what justifying reason was there to take the experience as veridical rather than hallucinatory? There isn't any sufficient reason (as far as one's present community is concerned) to make the jump from one interpretive community to another. For such a move would require (at the time of decision) that you prefer a bad (false) interpretation to a good (true) one. So this community standards gambit falls flat.

\section{The Fallacy of Story-ism}

Our original problem, you recall, was one of infinite regress. If Derrida's Axiom is true, everything is an interpretation. This immediately implies that in order to "make sense" of an interpretation, you need another interpretation. Think of a set of people, places, and events - say, the things we read about in our bibles. These are the things themselves. No one at the timenot even Jesus's disciples - experienced these things as they were; each was experienced as an interpretation. Later, the biblical authors recorded these events, and their record was also an interpretation, namely, their attempt to "make sense" of their experiences. But if DA is right, that record or story must also be interpreted for it to "make sense." But once we realize that we've just added another story on top of the previous two, we'll have to "make sense" of our latest interpretive effort. And then another story will be needed, and so on ad infinitum. To "make sense" of the gospel, then, we shall have to "read through" an infinite series of stories, which just isn't possible.

At the end of the day, Smith feels the force of this problem. And he does move to terminate the regress - with a story based on the right presuppositions. Thus he writes,

What is required to interpret the world well are the right presuppositions. But as Paul repeatedly emphasizes, these conditions are themselves a gift; in other words, the presuppositions and horizons that make it possible to "read" creation are grace-gifts that attend redemption and regeneration. ${ }^{45}$

Once God presents us with the right set of presuppositions, we can interpret the world rightly. One might even say, God gives us the right context and rules for interpretation. Now if this were the case, not only would it provide a

45. Smith, "A Response to the "Biola School," 218. In a fascinating remark, Smith actually invokes the giants of presuppositional apologetics in support of his perspectivalism. He writes: "I think that presuppositional apologetics ... such as that developed by Francis Schaeffer, but also Cornelius Van Til and, to a degree, Herman Dooyeweerd - rejects classical apologetics because it recognizes the truth of the postfoundationalist claim that everything is interpretation" (ibid). It is beyond the scope of our paper to assess Smith's contention here. 
method for sifting good from bad interpretations, our regress problem would vanish; our bookshelf would have an end - with a story based on a unique, divinely given set of presuppositions.

It's important to note how Smith puts this: these new presuppositions attend regeneration. It's not that there is a change in you (say, an enhancing of your cognitive powers to grasp reality as it is). It's rather that God delivers to you a new set of interpretive glasses through which you see the world as his creation. You get a new and different story, but in point of fact you're still as far away as ever from knowing that what this new story says is the case really is the case. For what objective reason could there be for you to think these new presuppositions are actually the right ones, while all the others wrong? None so far as we can see. In fact, if DA is true, these presuppositions would also have to be interpreted; we wouldn't know what they were in themselves, but only how we experienced them given our context, history and background, "and more." 46

What we have here, at best, is a mere reshuffling of our presuppositions, one for which there is no justification. All you can say is that, according to your set of presuppositions, the world is God's creation. But of course the atheist will counter by insisting that on his presuppositions, the world is not created; it has either existed from infinity past or sprung into being from nonbeing for no reason.

Of course, Smith might reply, "I never intended 'true' to be taken in any robust epistemic sense. When I say that the 'creation' story is right, all I mean is that it's the creation interpretation supplied to us by the Creator." In other words, it's right because it comes from the right source. But the question is: how would Smith ever know this? He might be tempted to say it is because scripture says his presuppositions are true. But such a response is doomed to failure. First, it assumes that which is to be proven. It is obviously a case of (vicious) circular reasoning to argue, "The biblical story is true because it's based on the right presuppositions. And we know these presuppositions are true because they are taught in the true biblical story!"

But things get even worse for Smith. For we can't even say (on his view) that's what the Bible says because there's no access to anything like that. All we have are the many interpretations of what it says. And there is no objective way to adjudicate between them. We can't appeal to the facts; there are no uninterpreted facts: "even experiencing a cup 'in person' or 'in the flesh' demands that I interpret the thing as a cup." ${ }^{.47}$ Strangely enough, therefore, the disciples didn't preach the facts about Jesus's resurrection (his empty tomb, his appearances). That wasn't possible. So they did the best they could; they told their story - an interpretation for which, in principle, they could provide no evidence. How could they? There is nothing outside

46. Smith, Who's Afraid of Postmodernism?, 52.

47. Smith, "A Response to the "Biola School,", 225. 
interpretations, and that's just where the evidence, if any, would exist. In doing so, then, they were clearly guilty of what we could call story-ism: favoring one's own story over others without legitimate reason or justification.

It's likely that Smith would object to this charge by arguing that there is a legitimate reason for accepting the Christian story. The Christian story brings the most order to our disarrayed affective registers. The story has a pragmatic justification; we accept it because it works. But isn't that exactly what non-Christians are going to say about their stories? Of course it is. The only recourse here is to inform our Buddhist, Muslim, and atheist friends that they are factually wrong; their stories do not (and will not) correctly order their affective registers. They think their stories effect this ordering, but they are just mistaken. Not only is this condescending apart from a justifying reason, but it's unclear how someone like Smith is even in a place to make such a judgment. He has no objective basis for saying that their stories fail to order their affective registers. Nor does he have any nonrelative grounds for saying that they are in need of ordering in the first place. The most he can do is to say that according to his story their affective registers are disordered and need straightening out. On his story, the Christian community has a story that can bring about that proper ordering. On his story, the Christian story "fits" his affective register. But to claim that it will do the same for others is to assume something he expressly denies: that we have access to the way things really are with the affective registers of others.

\section{Where Did the Gospel Go?}

Here is a second way to unpack the concept of fit. Perhaps the "fit" obtaining between a story and our emotional lives is to be understood along coherentist lines. The narrative acts as a web of sorts, and our theory laden emotions somehow fit into or cohere with the larger story, which then provides the larger context to interpret them.

Here there is much to say, but we'll mention just a few of the more pressing points. First, we must note that in epistemological contexts, the notion of "fit" or coherence is typically parsed in terms of propositions or belief. Very roughly, a belief $b$ is said to "fit" or cohere with one's total belief set just in case $b$ is consistent with every belief in that set; that is to say, the conjunction of $b$ with everything else one believes yields no contradiction. Although there are well known difficulties with equating truth or justification with coherence (thus construed) ${ }^{48}$ the concept is at least reasonably clear. We know with a fine-grained clarity what it is for a set of beliefs to be explicitly contradictory. If that set deductively implies a belief (or proposition)

48. See Alvin Plantinga, Warrant: The Current Debate (New York: Oxford University Press, 1993), chaps. 4-5. 
of the form $p$ and not- $p$, it is incoherent. If not, then —all other things being equal - it is coherent.

The question is whether this general notion of coherence happily applies to the "fit" we might want to say obtains between a narrative and one's affective register. And it's not obvious that it does. As Smith himself says, "A narrative makes sense of a life, a series of events, or an experience by a "logic" that is not deductive but affective. The linkage and production of meaning are not the result of a cognitive inference but rather of an affective construal." 49 What is an affective "logic" or "construal"? Smith's answer isn't wholly clear. It is, he says, an affective or emotive organizing of our emotions, which are "themselves already "construals' of the world." ${ }^{50}$ So it's an emotive organization of emotions. Now, presumably, there is a right and a wrong way to do this sort of thing. One wonders then: are there emotional "contradictions"? What does it mean to say that one's affective register is coherent? Can one emotion "entail" another? Well, we simply aren't told.

Still, perhaps we have a rough and ready idea of what Smith has in mind. Intuitively, one thinks, a properly ordered register of affections and emotions wouldn't be a mere chronological sequencing, but more a matter of having the right emotions - that is, those appropriate to the circumstance - and the right affections (say, loving the things we ought to love, and hating the things we ought to hate). For the most part, our affective registers aren't arranged this way, but the implication is that they ought to be. And stories, we are told, help to "make sense" of things along these lines.

We are now in a position to see what the "fit" between an affective story and affective register might come to. When your affective register is arranged the way a story suggests it should be, there is a "fit" or proportionality between story and register. If not, then not. We can also safely assume that fit or coherence is a degreed notion. Some stories "fit" or make better sense than others. Some tell us that our affective registers are nicely ordered; others that they are badly in need of alignment. Accordingly, if story-fit is the affective goal - and when you set objective truth aside, what else could it be? - then surely one ought to embrace the story with the greatest degree of "fit" with one's affective register.

But now consider the gospel. How well does it "fit" with the unbelieving heart? Quite badly, we're afraid. ${ }^{51}$ But this is no slight on the gospel; it is perfectly designed to accomplish its purpose. It is an offense to human pride - and intentionally so. As the Apostle says, "the message about the cross is foolishness to those who are perishing ... a stumbling block to Jews and foolishness to Gentiles" (1 Cor. 1:18, 23). In other words, the gospel story doesn't "fit" with the affective registers of "those who are perishing."

49. Smith, Thinking in Tongues, 65.

50. Ibid.

51. We owe this point to Don Horban. 
Paul says it shames the influential, those of noble birth, the wise, and the strong, "so that no one might boast in the presence of God" (1:29). Sounds like a complete lack of "fit" to us. But then shouldn't the unbeliever eschew the gospel story? If Smith is right, we certainly think so. It doesn't enhance affective organization; it disorders the unbeliever's emotional life and experience; and if we follow Smith, there are no facts to support it. Just ask Richard Dawkins; he'll tell you.

The upshot is this. If the gospel really is good news, then everyone should accept it. And if not everyone, well then it isn't good news after all. But that is what "gospel" means: good news. So you've got no gospel. For Dawkins, the story of descent with modification produces the greatest "fit"; it "makes sense" of his affective register, so he says, and everything else besides. And since, for Smith, "The truth is the story," Darwinism is "true"-not absolutely and objectively of course; for that would deny Derrida's Axiom — but rather true for Dawkins. That's his truth. What we have here is relativism straight up. That's what you get when you disconnect stories from the objective facts. A story could fail to correspond with reality in every way, and yet still "make sense" of your affective register and thus count as your truth.

Now we have no doubt that Smith will not be happy with what has been said about his view. Perhaps he would respond that everyone ought to accept the Christian story because it's best - or at least better than the others he knows about. But Smith hasn't left himself this option. For he is on record as saying that the criteria for evaluating the claims of a story are story-relative. That means you can't impose your story-relative rules of assessment on other stories that don't include those rules. You can't even accuse others of living or endorsing inconsistent stories; for the "laws" of logic are also story dependent. Thus according to Smith,

The criteria that determine what constitutes 'evidence' or 'proof' must be game-relative: they will function as rules only for those who share the same paradigm or participate in the same language game. ... The incommensurability of language games means that there is a plurality of logics that preclude any demonstrative appeal to a 'common reason' ... the rules for distinct games are not proportional. ${ }^{52}$

In short, you've sealed yourself in a hermeneutic bubble. You can't objectively criticize other stories; indeed, Smith's story-relativism may well hamper the holy grail of postmodernism-conversations. (Think of all the trouble poor Alice had trying to communicate with those strange characters in the Wonderland language game.)

You might reply that our critique is based on a flawed understanding of how stories are adopted in the first place. A Calvinist who held Smith's view - Smith himself perhaps - could say that God gives irresistible grace

52. Smith, "A Little Story about Metanarratives," in Christianity and the Postmodern Turn, 132. 
to the elect, and that necessarily involves a presuppositional (story) replacement. Hence, the Christian story isn't chosen by us so much as it is impressed upon us, perhaps in such a clear and forceful way that we see it as it is, and not merely as we interpret it given the context in which it is encountered, our history, background, and the like. We can then dismiss the charge of relativism; those who irresistibly receive the Christian story have true presuppositions; those who don't (through no fault of their own) have false stories.

The difficulty, of course, is that while this move helps with the earlier criticism that unbelievers could be within their rights in rejecting the gospel (on grounds of lack of "fit"), it creates a problem of equal severity. For now, on the Calvinist option, irresistible grace brutely imposes the gospel story on even opposing affective registers. But this makes hash of the idea that anyone should embrace the gospel. For the elect believer, there's no should about it; it's your story whether you like it or not. And for the non-elect: it scarcely makes sense to say they ought to embrace what they cannot. (After all, they're still waiting for that elusive shot of irresistible presuppositions. ${ }^{53}$ )

Take a couple of steps back. Think about Smith's overall metanarrative about stories. Think about Derrida's Axiom. It's not just a suggestion, is it? It has the look and feel of preaching - preaching from a higher vantage point, preaching about everything (stories, affections, life, experience, interpretation, truth, language games, evidence, and proof). You might wonder, as we have, where Smith's sermon is being delivered from. We've done our level best, but still cannot shake the feeling that it's the dreaded view from nowhere. If so, then as a good narrative postmodernist, Smith would do well to remember these words (inscribed by him but inspired by Lyotard): "no neutral observer or 'God's-eye-view' can legitimate or justify one paradigm or language game above another." ${ }^{54}$ But then shouldn't Smith stop trying to do just that?

The subtitle of one of Smith's many fine books is "Taking Derrida, Lyotard, and Foucault to Church." With that we can all happily agree. Certainly, they should be taken to church. As far as their ideas go, however, that is another matter. It may well be, as Smith tells us, that pentecostalism (with

53. One might object, as did an anonymous referee, that we've shown how the various ways in which one might understand Smith's epistemological project fail, but we've not yet provided an alternative of our own. That is, if we are right and Smith's project is a failure, then what should one embrace instead? We think this is an important question, but it simply falls outside the scope of the paper. Providing an alternative to Smith's view is not necessary to show that his view is unsatisfactory. This, we take it, is the underlying point Alvin Plantinga is making when he writes, "If you think a given explanation or theory T is less likely than its denial, or even if you think it is only somewhat more likely than its denial, you quite properly won't believe it. This is so even if you can't think of another theory or explanation of the phenomena that you believe more probable than not, or even more probable than T" (Alvin Plantinga, "On Rejecting the Theory of Common Ancestry: A Reply to Hasker," Perspectives on Science and Faith 44 (1992): 259).

54. Smith, "A Little Story about Metanarratives," 131; cf. The Fall of Interpretation, 177. 
its stress on the importance of personal experience of God) will find itself initially attracted to story and narrative as a vehicle for testimony. But the attraction rather abates once one realizes there is a full blown epistemology along for the ride: one that equates truth with stories, while conceding a plurality of gospel-denying stories. The unwary pentecostal therefore finds himself committed to either an untenable story-relativism (where no story-not even the gospel - is epistemically privileged) or a question-begging storyism (privileging one's own story over others without justification). In particular, he cannot escape the fact that equating truth with story "fit" inevitably provides an excuse to those we are told are "without excuse" (Rom. 1:20). It is difficult in excelsis, therefore, to see why pentecostals should be drawn to Derrida's Axiom at all. We respectfully submit, therefore, that pentecostal Christians should treat this brand of postmodernism as just that sort of philosophy Paul tells us "depends on human tradition and the basic principles of this world rather than on Christ" (Col. 2:8). ${ }^{55}$

55. A previous version of this paper was presented at the 2013 Annual Meeting of the Society for Pentecostal Studies, held at Seattle Pacific University. We are thankful to the participants in the Philosophy Interest Group for their helpful comments and feedback, in particular William Kay and Jack Wisemore. In addition, we are also thankful to Dale Coulter, Joe Gorra, Van Johnson, and two anonymous referees for their helpful feedback on earlier drafts of this paper. 